\title{
Perineal Management: Confidence And Educational Needs Among Midwives In Selected Health Facilities In Mityana District, Uganda. A Descriptive Cross-Sectional Study
}

\author{
Jackline Nakimulia,1, Ihudiebube-Splendor Chichaodili $\mathbf{N}^{\mathrm{a}}$ \\ a Department Of Midwifery, University of Port Harcourt, \\ Nigeria, East/West Road, PMB 5323 Choba, Rivers State, Nigeria
}

\section{Abstract}

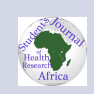

\section{Background:}

Midwives are principal professionals providing woman-centered continuity of care for childbearing women worldwide. Perhaps there are inadequate evidences to infer of whether there are differences in illness and deaths, usefulness and psycho social results between models of care that is midwife-led and other care models.

\section{Methodology:}

A descriptive cross-sectional study was used where a Self-administered and semi-structured questionnaire with both closed and open-ended questions was used to collect data.

\section{Results:}

The level of confidence at perineal management and managing vaginal deliveries is directly influenced by level of education attained by the midwife. From the study findings, midwives who had attained a degree in midwifery expressed more confidence at perineal management and vaginal deliveries than those with a diploma and certificate in midwifery. Study findings also showed that midwives with the least time of exposure (work experience, those with fewer than a year of working experience expressed low levels of confidence towards perineal management and vaginal deliveries.

\section{Conclusions:}

The findings from this study demonstrate= that midwives crave for additional educational opportunities in perineal management, especially, in prevention strategies. They demanded the up-to-date evidence and best practice recommendations to provide guidance to midwifery perineal management. This shows that the midwives' were enthusiastic for continuous evaluation of their practices and commitments to life-long learning. It is therefore anticipated that midwives tailored educational programme that will not only improve clinical skills and perineal protection techniques but also confidence in decision-making be established to meet midwifery needs

\section{Recommendations: ${ }^{a}$}

Midwives should embark on 'back to basics' approach, they should continuously review the Anatomy and physiology, including the perineum and pelvic floor and mechanism of labour. This paucity of knowledge may be as a consequence of previous limited focus on anatomy of the perineum in earlier preregistration midwifery curricula and existing perineal management workshops.

\begin{tabular}{lll}
\hline \multicolumn{1}{c}{ Date Submitted:10-10-2021 } & Date \\
Accepted:13-11-2021 Email: & jack- \\
nakimuli@gmail.com & &
\end{tabular}




\section{Background to the study}

Perineal management is a major phase of women's health and newly birthed mothers need this followup care and some beyond the postpartum period (Steen, 2012). Midwives are principal professionals providing woman-centered continuity of care for childbearing women worldwide. Perhaps there is inadequate evidence to infer whether there are differences in illness and deaths, usefulness, and psychosocial results between models of care that is midwife-led and other care models (Sandall, Soltani, Gates, Shennan\&Devane, 2016).

A global public health challenge remains the midwives' confidence and educational needs in the management of the woman's perineum. About, $85 \%$ of women have perineal and vaginal trauma such as tears, episiotomies, or vaginal lacerations during childbirth (Kettle \&Tohill, 2011). Thankfully, continuous education and training have helped midwives to gain confidence in clinical skills to keep them up-to-date and competent with the best available evidence on how to base their perineal management in particular (Steen, 2012).

In the United Kingdom (UK), how perineum was managed would rest upon the method of assessment, repair, and follow-up care and these may have significant long-term effects for women (Bick, Ismail, Macdonald, 2012). In a study, about $10 \%$ of the 607 midwives did not undergo training on perineum assessment and recognition of anal sphincter injury (Trochez, Waterfield\& Freeman, 2011). Despite midwives feeling confident to appraise perineal injury at all times, only 116 (34.3\%) midwives and even fewer $73(21.6 \%)$ could have the confidence to do the perineal repair at all times(Bick, Ismail\&Macdonald, 2012).

The dearth of trained qualified health professionals is a notorious finding in Africa; it has massively affected the maternal and child health indices by impacting the training and deployment of midwives (Hildingsson, Rubertsson, Karlström\& Haines, 2019). Estimates from twenty-three (23) countries Demographic and Health Surveys since 2015 showed that Mali (34.5\%) and Senegal (29.5\%) had higher facility-based deliveries than skilled birth attendant coverage and some women facilitybased births (Mothers)reported to have been assisted by nonskilled birth attendants (Radovich, Benova, Penn-Kekana, 2019).
According to the 2017 Global Health Observatory of the World Health Organization (WHO) members reported situations states of less than three (3) nursing/midwifery personnel per 1000 population, nearly $25 \%$ reported to have less than 1 per 1000 patients in low-income countries (WHO, 2017). In East Africa, as it is in many evolving regions, there is a huge disparity in the cadres and competence of midwives (Adegoke, Utz, Msuya, \& van den Broek, 2012).

Notably, the shortage of midwives in Uganda remains a primary worry yearly. The midwife-topatient ratio of 6 to 100,000 is indicative of the dearth of these health workers in the country, which is too low compared to that of WHO recommendation of 2.5 to 1000 (WHO, 2017). Many midwives in Uganda have certificates at the diploma level and are trained to confidently manage normal pregnancy, labour, postpartum and newborn care but not complications of pregnancy, labour, or the leading causes of maternal and newborn deaths (Munabi-Babigumira, Nabudere\&Asiimwe, 2019).

Mityana District has 59 health facilities and its Health department has the mandate to provide basic Primary Health Care through equitable delivery of quality services to the community leading to social and economic productive life $(\mathrm{MoH}, 2018)$. Gaps in essential equipment, inadequate handson in-service training, mentorship, and supervision of health workers remain a challenge. It is crucial to identify how midwives in the Mityana district manage perineal conditions during childbirth and the extent to which perineal management reflected the confidence and education-based guidance of midwives.

\subsection{RESEARCH METHODS}

\subsection{Study design}

A descriptive cross-sectional study and it involved qualitative and quantitative data collection method. It was descriptive because it allows individuals to describe circumstances in their typical place. A cross-sectional study was chosen because it was to be used to describe what was happening at the present moment in a defined population in a specific period.

\section{Study setting}

This study was carried out in Mityana hospital and selected health centers III's and IV's in Mityana district, Uganda. Mityana is the main commercial 
and administrative town that lies in Uganda's central region. It is the district capital city and covers, around 77 kilometers by road, west of Kampala, Uganda's capital headquarters and largest city. The town lies halfway between Kampala and Mubende on an all-weather tarmac highway linking Uganda's capital city with the Fort Portal town in the western region. Mityana district has 59 health facilities in the district which are government-owned comprising a district general hospital, health center IV's, health center III's, and health center II's. These health facilities in Mityana have a staffing structure of fortynine staff at each health center IV, nineteen staff at each health center III, and eight staff at each health center II. The healthcare facilities operate under dissimilar circumstances and are located in different areas of the district. They primarily cater to the health needs of the town dwellers as well as rural subsistence farmers that live in the communities where the health facilities are located. Advances in medical facilities, an increase in the number of patients, and the introduction of more maternal child health services have increased its demands in these health facilities.

\section{Study population}

The study targeted midwives who assist with deliveries in the labour ward of Mityana hospital and selected health center III's and IV's. Mityana district has sixty-four (64) midwives working in various health centers III's, IV's, and in a hospital within the district. These midwives play key roles in the care of women during spontaneous vaginal births that embrace responsibility for perineal assessments and repairs all the time.

\subsection{Sample size determination}

$$
\mathrm{n}=\left(\frac{\mathrm{N}}{1+\mathrm{N}(\mathrm{e})^{2}}\right)
$$

Yamane's formula (1967), which state that Where; $n$ desired sample size,

$e=$ the desired level of precision at $5 \%(0.05)$ at $95 \%$ confidence interval.

$\mathrm{N}=$ is the population size of desired characteristics, midwives who assist with deliveries in the labour ward of Mityana hospital and selected health centre III's and IV's in Mityana district, Uganda. $\mathrm{N}=64$ as per Mityana Health District report 2020.
In this case, 95\% was the confidence level and $5 \%$ was the acceptable limit of error

$$
n=\left(\frac{64}{1+64(0.05)^{2}}\right)
$$

$\mathrm{n}=55$

Therefore, the sample size, $\mathrm{n}=55$ participants.

\section{Sampling procedure}

A simple random sampling technique was used to choose the study participants. Participants were selected based on chances to participate in the present study as long as he or she voluntarily accepted to participate in the study.

\section{Inclusion criteria}

The researcher only included midwives who assist with deliveries in the labour ward of Mityana hospital and selected health center III's and IV'spresent during the time of study and willingly accepted to participate voluntarily in the study.

\section{Exclusion criteria}

Midwives who assisted with deliveries in the labour ward of Mityana hospital and selected health center III's and IV's found on any kind of leave and any participants who were present, but not willing to take part voluntarily during the time of the study were excluded.

\section{Study variables \\ Dependent variable}

Perineal management in a selected health facility in Mityana district, Uganda

\section{Independent variables}

Midwives'confidence in perineal management in selected health facilities in Mityana district, Uganda.

Midwives educational needs on perineal management in selected health facilities in Mityana District, Uganda.

Socio-demographic characteristics such as educational status, age, marital status, religion, and years of experience of midwives in selected health facilities in Mityana district, Uganda.

\section{Research instrument}

A self-administered and semi-structured questionnaire with both closed and open-ended questions developed under the supervision and written in the English language were used for data collection. It included three sections; section A had socio-demographic characteristics, section $B$ for midwives' confidence in perineal management, and 
section C for midwives' educational needs on perineal management in selected health facilities in Mityana District, Uganda.

\section{Validity and reliability of research instru- ment}

The validity of the instrument was defined by presiding the project by the supervisor and the research ethics committee who may be experts in the field of obstetrics and gynecological management. They reviewed the relevancy of content about the purpose of the study and research questions sensibility for effective soundness.

The reliability of the research instruments was pre-tested on five midwives who assist with deliveries in the labour ward of Mubende hospital before the start of the original study to check its dependability.

\section{Data collection procedures}

The researcher did a self-introduction to participants. Rapport was created with the midwives and then questionnaires were distributed to the qualified participants at various shifts. Completed questionnaires were retrieved immediately after completion to account for the response rate. Data was collected from Monday - Friday (5 days) to allow full coverage of the participants who are on shift duties. Data collection took place within two months. The midwives got in their respective wards and on average of about 4 participants were contacted to participate voluntarily in the study.

\section{Data management}

All collected data from the questionnaires were checked and kept confidential to avoid any reach by unauthorized personnel except the principal researcher. This helped the researcher to protect the intimacy and privacy of the interviewed participants.

Data analysis and presentation

The quantitative data from the filled questionnaires were compiled, checked for consistency, and coded by using Microsoft excel/word, and analyzed using Statistical Package for Social Sciences (SPSS) version 18.0. It was presented on graphs, frequency distribution tables, and simple narrations for interpretation, discussion, recommendation, and conclusion.

\section{Ethical considerations}

Following proposal presentation and approval, go-ahead permission to conduct the research study was got from the supervisor, research, and ethics committee from the African center of excellence for Public Health and Toxicological research at the University of Port Harcourt. An introductory letter was given to the researcher which was addressed to the District Health Officer of Mityana district to allow the researcher to collect data. The purpose of the study was explained to participants for informed consent. Consent was obtained from the participants before issuing the questionnaires and their refusal will not tip to any punishment.

\section{Socio demographic characteristics}

resents the Socio-demographic characteristics of the study participants. Results in this study show that the age of respondents ranged from 20 to 59 years, with a mean age of 31.7 Majority (52.7\%) of aged 20-29 years. Most 30 (54.6\%) were not married. The majority of the participants $29(52.7 \%)$ had attained a certificate in midwifery, well as 23 (41.8\%) had attained a diploma in midwifery and $3(5.5 \%)$ had attained a degree in midwifery. All respondents were Christians. Most 20 (36.4\%) had a work experience in midwifery of 0-2 years, 15 (27.2\%) had a work experience of 9-11 years, 18.2\% (10) had a work experience of 3-5 years and 18.2\% (10) had a work experience of 6-8 years. Mean work experience was 5.09 and standard deviation 3.71

\section{Midwives confidence on perineal management}

Results from Table 2 above show that majority of the respondents (midwives) had strong confidence (I am very confident, even independently, with back up for problems) at perineal management and vaginal delivery.

Midwives with a certificate in midwifery that had strong confidence in perineal management; 20 (69\%) very confident guiding perineum during vaginal delivery, 11 (37.9\%) very confident at managing perineal bleeding, 7 (24.1\%) very confident at suturing any degree of perineal tear, 14 (48.3\%) very confident at perineal assessment and 7 (24.1\%) very confident at classifying perineal tears.

Midwives with a diploma in midwifery that had strong confidence in perineal management; 23 $(100 \%)$ very confident guiding perineum during vaginal delivery, 20 (86.9\%) very confident at managing perineal bleeding, 18 (78.3\%) very confident at suturing any degree of perineal tear, 22 
Table 1. Socio-demographic characteristics of the respondents $n=55$

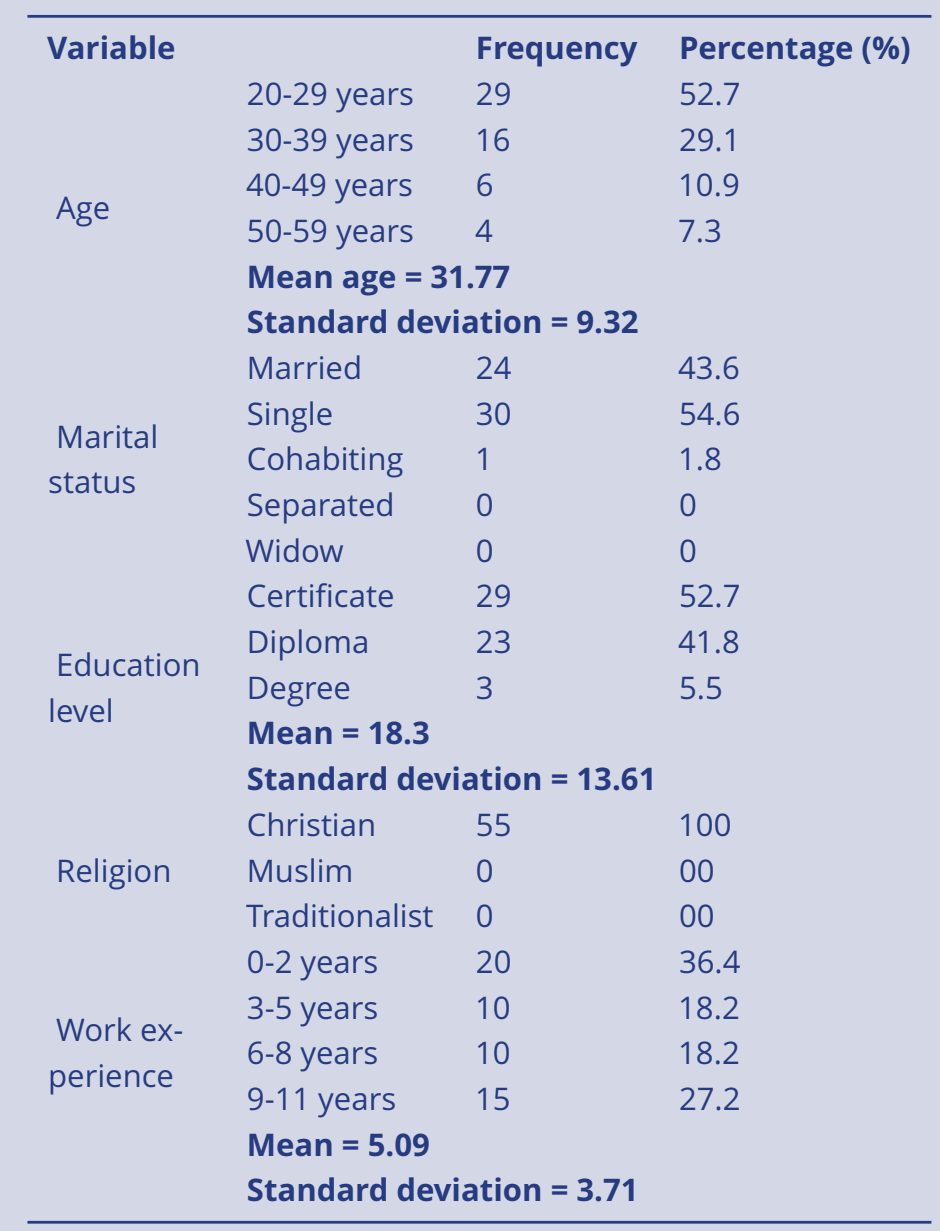

(95.6\%) very confident at perineal assessment and $18(78.3 \%)$ very confident at classifying perineal tears.

Midwives with a degree in midwifery that had strong confidence in perineal management; 3 (100\%) very confident guiding perineum during vaginal delivery, 3 (100\%) very confident at managing perineal bleeding, 3 (100\%) very confident at suturing any degree of perineal tear, $3(100 \%)$ very confident at perineal assessment and $3(100 \%)$ very confident at classifying perineal tears.

Study findings from Figure 2 above show Midwives with a certificate in midwifery that had strong confidence at managing vaginal delivery; 20 (68.9\%) very confident controlling the head during labor, 17 (58.6\%) very confident at delivering shoulders, 15 (51.7\%) very confident delivering after shoulders, $23(79.3 \%)$ very confident delivering the placenta and $3(10.3 \%)$ very confident examining the placenta.

Midwives with a diploma in midwifery that had strong confidence at managing vaginal delivery; 20
(86.9\%) very confident controlling the head during labor, 18 (78.3\%) very confident at delivering shoulders, 23 (100\%) very confident delivering after shoulders, $23(100 \%)$ very confident delivering placenta and 10 (43.5\%) very confident examining the placenta.

Midwives with a degree in midwifery that had strong confidence at managing vaginal delivery; $3(100 \%)$ very confident controlling the head during labor, $3(100 \%)$ very confident at delivering shoulders, $3(100 \%)$ very confident delivering after shoulders, $3(100 \%)$ very confident delivering placenta and $3(100 \%)$ very confident examining the placenta.

Midwives with a work experience of 0-2 years that had strong confidence in perineal management; 11 (55\%) very confident guiding perineum during vaginal delivery, 4 (20\%) very confident at managing perineal bleeding, $2(10 \%)$ very confident at suturing any degree of perineal tear, $5(25 \%)$ very confident at perineal assessment and $2(10 \%)$ very confident at classifying perineal tears. 
Table 2. Midwives confidence on perineal management

\begin{tabular}{|c|c|c|c|c|c|c|c|}
\hline & How would you rate & Current lev & el of conf & dence & & Mean & Standard de- \\
\hline & $\begin{array}{l}\text { confidence? Key: } 1 . \\
\text { I am not at all } \\
\text { confident; } 2 \text {. I am } \\
\text { somehow confident } \\
\text { with close } \\
\text { hand-to-hand } \\
\text { assistance; } 3 . \text { I am } \\
\text { confident with minimal } \\
\text { supervision; } 4 \text {. I am } \\
\text { very confident, even } \\
\text { independently, with } \\
\text { back up for problems }\end{array}$ & $\begin{array}{l}\text { (1) I am } \\
\text { not at } \\
\text { all confi- } \\
\text { dent. }\end{array}$ & $\begin{array}{l}\text { (2) } \\
\text { I am } \\
\text { some- } \\
\text { how } \\
\text { confi- } \\
\text { dent } \\
\text { with } \\
\text { close } \\
\text { hand- } \\
\text { to- } \\
\text { hand } \\
\text { assis- } \\
\text { tance. }\end{array}$ & $\begin{array}{l}\text { (3) I am } \\
\text { confi- } \\
\text { dent with } \\
\text { minimal } \\
\text { supervi- } \\
\text { sion. }\end{array}$ & $\begin{array}{l}\text { (4) I am } \\
\text { very con- } \\
\text { fident, } \\
\text { even } \\
\text { indepen- } \\
\text { dently, } \\
\text { with back } \\
\text { up for } \\
\text { prob- } \\
\text { lems. }\end{array}$ & & \\
\hline 6 & $\begin{array}{l}\text { I wash my hands first } \\
\text { before starting perineal } \\
\text { care. }\end{array}$ & $0(0 \%)$ & $0(0 \%)$ & $4(7.3 \%)$ & $51(92.7 \%)$ & 13.75 & 24.9 .5 \\
\hline 7 & $\begin{array}{l}\text { I wipe my hands and } \\
\text { wear gloves before } \\
\text { starting perineal care }\end{array}$ & $0(0 \%)$ & $\begin{array}{l}2 \\
(3.6 \%)\end{array}$ & $6(10.9 \%)$ & $47(85.5 \%)$ & 13.75 & 22.307 \\
\hline 8 & $\begin{array}{l}\text { I provide privacy before } \\
\text { starting perineal care }\end{array}$ & $0(0 \%)$ & $\begin{array}{l}1 \\
(1.8 \%)\end{array}$ & $7(12.7 \%)$ & $47(85.5 \%)$ & 13.75 & 22.381 \\
\hline 9 & $\begin{array}{l}\text { I explain every proce- } \\
\text { dure to the patient dur- } \\
\text { ing perineal care }\end{array}$ & $0(0 \%)$ & $0(0 \%)$ & $5(9.1 \%)$ & $5(9.1 \%)$ & 2.5 & 2.887 \\
\hline 10 & $\begin{array}{l}\text { I can Assess the patient } \\
\text { and Identify the need } \\
\text { for perineal care }\end{array}$ & $0(0 \%)$ & $0(0 \%)$ & $9(16.4 \%)$ & $46(83.6 \%)$ & 13.75 & 21.915 \\
\hline 11 & $\begin{array}{l}\text { I am confident, I can Ex- } \\
\text { amine the patient for } \\
\text { degree of tears during } \\
\text { deliveries }\end{array}$ & $0(0 \%)$ & $\begin{array}{l}1 \\
(1.8 \%)\end{array}$ & $6(10.9 \%)$ & $48(87.3 \%)$ & 13.75 & 22.984 \\
\hline 12 & $\begin{array}{l}\text { I am confident to guide } \\
\text { the perineum during } \\
\text { vaginal delivery }\end{array}$ & $0(0 \%)$ & $0(0 \%)$ & $9(16.4 \%)$ & $46(83.6 \%)$ & 13.75 & 21.915 \\
\hline 13 & $\begin{array}{l}\text { I am confident in per- } \\
\text { forming antenatal per- } \\
\text { ineal massage }\end{array}$ & $\begin{array}{l}14 \\
(25.5 \%)\end{array}$ & $\begin{array}{l}5 \\
(9.1 \%)\end{array}$ & $13(23.6 \%)$ & $23(41.8 \%)$ & 13.75 & 7.365 \\
\hline 14 & $\begin{array}{l}\text { I can confidently man- } \\
\text { age any perineal bleed- } \\
\text { ing }\end{array}$ & $2(3.6 \%)$ & $\begin{array}{l}3 \\
(5.5 \%)\end{array}$ & $16(29.1 \%)$ & $34(61.8 \%)$ & 13.75 & 14.93 \\
\hline 15 & $\begin{array}{l}\text { I can confidently suture } \\
\text { any degree of teers dur- } \\
\text { ing delivery as indicated }\end{array}$ & $1(1.8 \%)$ & $\begin{array}{l}6 \\
(10.9 \%)\end{array}$ & $20(36.4 \%)$ & $28(50.9 \%)$ & 13.75 & 12.447 \\
\hline 16 & $\begin{array}{l}\text { I can confidently do Per- } \\
\text { ineal assessment }\end{array}$ & $0(0 \%)$ & $\begin{array}{l}2 \\
(3.6 \%)\end{array}$ & $14(25.5 \%)$ & 39 (70.9\%) & 13.75 & 17.933 \\
\hline 17 & $\begin{array}{l}\text { I can confidently Per- } \\
\text { form perineal examina- } \\
\text { tion }\end{array}$ & $0(0 \%)$ & $\begin{array}{l}2 \\
(3.6 \%)\end{array}$ & $10(18.2 \%)$ & $43(78.2 \%)$ & 13.75 & 19.973 \\
\hline 18 & $\begin{array}{l}\text { I can confidently } \\
\text { Perform Right medio- } \\
\text { lateral technique for } \\
\text { Episiotomy }\end{array}$ & $0(0 \%)$ & $\begin{array}{l}3 \\
(5.5 \%)\end{array}$ & $18(32.7 \%)$ & $34(61.8 \%)$ & 13.75 & 15.628 \\
\hline 19 & $\begin{array}{l}\text { I can confidently Clas- } \\
\text { sify perineal tears }\end{array}$ & $1(1.8 \%)$ & $\begin{array}{l}6 \\
(10.9 \%)\end{array}$ & 20 (36.4\%) & $28(50.9 \%)$ & 13.75 & 12.447 \\
\hline
\end{tabular}


Midwives with a work experience of 3-5 years that had strong confidence in perineal management; 10 (100\%) very confident guiding perineum during vaginal delivery, $8(80 \%)$ very confident at managing perineal bleeding, $6(60 \%)$ very confident at suturing any degree of perineal tear, $10(100 \%)$ very confident at perineal assessment and 7 (70\%) very confident at classifying perineal tears.

Midwives with a work experience of 6-8 years that had strong confidence in perineal management; 10 (100\%) very confident guiding perineum during vaginal delivery, 10 (100\%) very confident at managing perineal bleeding, $6(60 \%)$ very confident at suturing any degree of perineal tear, 10 (100\%) very confident at perineal assessment and $10(100 \%)$ very confident at classifying perineal tears.

Midwives with a work experience of 9-11 years that had strong confidence in perineal management; 15 (100\%) very confident guiding perineum during vaginal delivery, $12(80 \%)$ very confident at managing perineal bleeding, 12 (80\%) very confident at suturing any degree of perineal tear, 14 (93.3\%) very confident at perineal assessment and $11(73.3 \%)$ very confident at classifying perineal tears.

Midwives with a work experience of 0-2 years that had strong confidence in the management of vaginal delivery; 9 (45\%) very confident controlling the head during labor, 10 (50\%) very confident at delivering shoulders, 10 (50\%) very confident delivering after shoulders, 14 (70\%) very confidence delivering the placenta and none was very confident examining the placenta.

Midwives with a work experience of 3-5 years that had strong confidence in the management of vaginal delivery; $9(90 \%)$ very confident controlling the head during labor, 8 (80\%) very confident at delivering shoulders, 9 (90\%) very confident delivering after shoulders, $10(100 \%)$ very confident delivering placenta and 4 (40\%) very confident examining the placenta.

Midwives with a work experience of 6-8 years that had strong confidence in the management of vaginal delivery; $10(100 \%)$ very confident controlling the head during labor, 10 (100\%) very confident at delivering shoulders, $10(100 \%)$ very confident delivering after shoulders, 10 (100\%) very confident delivering placenta and 6 (60\%) very confident examining the placenta.
Midwives with a work experience of 9-11 years that had strong confidence in the management of vaginal delivery; 15 (100\%) very confident controlling the head during labor, 10 (66.6\%) very confident at delivering shoulders, 12 (80\%) very confident delivering after shoulders, $15(100 \%)$ very confident delivering placenta and 6 (40\%) very confident examining the placenta.3 Midwives educational needs on perineal management

The majority of the respondents strongly agreed with the educational need on perineal management: 25 (45.5\%) Basic approaches to labor (Anatomy, physiology, labor mechanism, perineal assessment, etc), 21 (38.2\%) Techniques and skills to prevent perineal tear, 18 (32.8\%) Birthing positions for reducing perineal tear, $22(40 \%)$ Techniques for perineal repairs, 23 (41.8\%) Timing for (when to perform) episiotomy, 20 (36.4\%) Anaesthetizing the perineum and 20 (36.4\%) Use of warm compress in birthing.

Educational requirements result from table 4 above show that: most 19 (34.5\%) strongly agreed with the protocol for perineal management exist in labour ward, 19 (34.5\%) strongly agreed with the availability of regular training and workshops on perineal management for midwives, 21 (28.2\%) strongly agreed with the availability of internship program for midwives to mentor them on new skills, 22 (40\%) strongly agreed that government invests much in training and retraining of midwives, $20(36.4 \%)$ strongly agreed with the availability of training programs for postgraduate and advanced level midwives, 19 (34.5\%) strongly agreed with the availability of sub-specialties in midwifery are being created to train specialist midwives, 21 (28.2\%) strongly agreed with

consultancy status for specialist midwives being implemented and 18 (32.8\%) strongly agreed to the availability of human simulation aids and used in all training programs.

\section{DISCUSSION, CONCLUSSIONS AND RECOMMENDATIONS}

\section{Discussion}

55 midwives who assist/conduct deliveries in the labour ward of Mityana hospital and other selected health center III's and IV's present during the time of the study, willingly accepted to participate in the study. 
Table 3. Midwives educational needs on perineal management

\begin{tabular}{|c|c|c|c|c|c|c|}
\hline & $\begin{array}{l}\text { Midwives educational needs on perineal } \\
\text { management }\end{array}$ & $\begin{array}{l}\text { Strongly } \\
\text { agreed }\end{array}$ & Agreed & $\begin{array}{l}\text { Dis- } \\
\text { agreed }\end{array}$ & $\begin{array}{l}\text { Strongly } \\
\text { dis- } \\
\text { agreed }\end{array}$ & $\begin{array}{r}\text { MeanStandard } \\
\text { deviation }\end{array}$ \\
\hline 25 & $\begin{array}{l}\text { Basic approach to labor (Anatomy, physiology, } \\
\text { labor mechanism, perineal assessment etc) }\end{array}$ & $\begin{array}{l}25 \\
(45.5 \%)\end{array}$ & $\begin{array}{l}19 \\
(34.5 \%)\end{array}$ & $\begin{array}{l}6 \\
(10.9 \%)\end{array}$ & $5(9.1 \%)$ & 13.759 .845 \\
\hline 26 & Techniques and skills to prevent perineal tear & $\begin{array}{l}21 \\
(38.2 \%)\end{array}$ & $\begin{array}{l}16 \\
(29.1 \%)\end{array}$ & $\begin{array}{l}7 \\
(12.7 \%)\end{array}$ & $11(20 \%)$ & 13.756 .076 \\
\hline 27 & Birthing positions for reducing perineal tear & $\begin{array}{l}18 \\
(32.8 \%)\end{array}$ & $\begin{array}{l}21 \\
(38.2 \%)\end{array}$ & $\begin{array}{l}8 \\
(14.5 \%)\end{array}$ & $8(14.5 \%)$ & 13.756 .752 \\
\hline 28 & Techniques for perineal repairs & $\begin{array}{l}22 \\
(40 \%)\end{array}$ & $\begin{array}{l}20 \\
(36.4 \%)\end{array}$ & $\begin{array}{l}7 \\
(12.7 \%)\end{array}$ & $6(10.9 \%)$ & 13.758 .421 \\
\hline 29 & Timing for (when to perform) episiotomy & $\begin{array}{l}23 \\
(41.8 \%)\end{array}$ & $\begin{array}{l}17 \\
(30.9 \%)\end{array}$ & $\begin{array}{l}5 \\
(9.1 \%)\end{array}$ & $\begin{array}{l}10 \\
(18.2 \%)\end{array}$ & 13.757 .89 \\
\hline 30 & Anaesthetizing the perineum & $\begin{array}{l}20 \\
(36.4 \%)\end{array}$ & $\begin{array}{l}20 \\
(36.3 \%)\end{array}$ & $\begin{array}{l}3 \\
(5.5 \%)\end{array}$ & $\begin{array}{l}12 \\
(21.8 \%)\end{array}$ & 13.758 .098 \\
\hline 31 & Use of warm compress in birthing & $\begin{array}{l}20 \\
(36.4 \%)\end{array}$ & $\begin{array}{l}15 \\
(27.3 \%)\end{array}$ & $\begin{array}{l}8 \\
(14.5 \%)\end{array}$ & $\begin{array}{l}12 \\
(21.8 \%)\end{array}$ & 13.755 .058 \\
\hline
\end{tabular}

\section{Table 4. Educational Requirements}

\begin{tabular}{|c|c|c|c|c|c|c|}
\hline SN & Educational Requirements & $\begin{array}{l}\text { Strongly } \\
\text { agreed }\end{array}$ & Agreed & $\begin{array}{l}\text { Dis- } \\
\text { agreed }\end{array}$ & $\begin{array}{l}\text { Strongly } \\
\text { disagreed }\end{array}$ & $\begin{array}{r}\text { Mean Standard } \\
\text { deviation }\end{array}$ \\
\hline 32 & $\begin{array}{l}\text { Protocol for perineal management exist in } \\
\text { labour ward }\end{array}$ & $\begin{array}{l}19 \\
(34.5 \%)\end{array}$ & $\begin{array}{l}6 \\
(10.9 \%)\end{array}$ & $\begin{array}{l}16 \\
(29.1 \%)\end{array}$ & $\begin{array}{l}14 \\
(25.5 \%)\end{array}$ & 13.755 .56 \\
\hline 33 & $\begin{array}{l}\text { There is regular trainings and workshops } \\
\text { on perineal management for midwives }\end{array}$ & $\begin{array}{l}19 \\
(34.5 \%)\end{array}$ & $\begin{array}{l}14 \\
(25.5 \%)\end{array}$ & $\begin{array}{l}8 \\
(14.5 \%)\end{array}$ & $\begin{array}{l}14 \\
(25.5 \%)\end{array}$ & 13.754 .5 \\
\hline 34 & $\begin{array}{l}\text { There is internship program for midwives to } \\
\text { mentor them on new skills }\end{array}$ & $\begin{array}{l}21 \\
(28.2 \%)\end{array}$ & $\begin{array}{l}5 \\
(9.1 \%)\end{array}$ & $\begin{array}{l}14 \\
(25.5 \%)\end{array}$ & $\begin{array}{l}15 \\
(27.2 \%)\end{array}$ & 13.756 .602 \\
\hline 35 & $\begin{array}{l}\text { Government invests much in training and } \\
\text { retraining of midwives }\end{array}$ & $22(40 \%)$ & $\begin{array}{l}11 \\
(20 \%)\end{array}$ & $\begin{array}{l}11 \\
(20 \%)\end{array}$ & $11(20 \%)$ & 13.755 .5 \\
\hline 36 & $\begin{array}{l}\text { There are training programs for Post } \\
\text { graduate and advanced level midwives }\end{array}$ & $\begin{array}{l}20 \\
(36.4 \%)\end{array}$ & $\begin{array}{l}10 \\
(18.2 \%)\end{array}$ & $\begin{array}{l}8 \\
(14.5 \%)\end{array}$ & $\begin{array}{l}17 \\
(30.9 \%)\end{array}$ & 13.755 .679 \\
\hline 37 & $\begin{array}{l}\text { Sub-specialties in midwifery are being } \\
\text { Created to train specialist midwives }\end{array}$ & $\begin{array}{l}19 \\
(34.5 \%)\end{array}$ & $\begin{array}{l}10 \\
(18.2 \%)\end{array}$ & $\begin{array}{l}10 \\
(18.2 \%)\end{array}$ & $\begin{array}{l}16 \\
(29.1 \%)\end{array}$ & 13.754 .5 \\
\hline 38 & $\begin{array}{l}\text { Consultancy status for specialist midwives } \\
\text { is being Implemented }\end{array}$ & $\begin{array}{l}21 \\
(28.2 \%)\end{array}$ & $\begin{array}{l}7 \\
(12.7 \%)\end{array}$ & $\begin{array}{l}10 \\
(18.2 \%)\end{array}$ & $\begin{array}{l}17 \\
(30.9 \%)\end{array}$ & 13.756 .397 \\
\hline 39 & $\begin{array}{l}\text { Human simulation aids are available and } \\
\text { used in all training programs }\end{array}$ & $\begin{array}{l}18 \\
(32.8 \%)\end{array}$ & $\begin{array}{l}11 \\
(20 \%)\end{array}$ & $\begin{array}{l}8 \\
(14.5 \%)\end{array}$ & $\begin{array}{l}18 \\
(32.8 \%)\end{array}$ & 13.755 .058 \\
\hline
\end{tabular}

The majority of the respondents (midwives) had strong confidence (I am very confident, even independently, with backup for problems) at perineal management and vaginal delivery $51(92.7 \%)$, as shown in the study findings.

Influence of some socio-demographic characteristics such as educational status, age, and years of experience on perineal management.

The level of confidence in perineal management and managing vaginal deliveries is directly influ- enced by the level of education attained by the midwife. From the study findings, midwives who had attained a degree in midwifery $3(100 \%)$, expressed more confidence at perineal management and vaginal deliveries than those with a diploma 20(86.9\%), and a certificate in midwifery 29(69\%).

Study findings also showed that midwives with the least time of exposure (work experience, those with less than one year of working experience 
20(36.4\%), expressed low levels of confidence towards perineal management and vaginal deliveries.

Study findings are similar to the UK and Australian studies where higher levels of confidence in perineal management were reported by inexperienced midwives ( Dahlen and Homer, 2008; Bick et al., 2012 ). Like Bick et al. (2012), this study also reported a lack of confidence amongst newly qualified midwives regarding perineal management during or after labor.

\section{Conclusion}

This study was aimed at assessing the midwives' confidence and educational needs on perineal management in selected health facilities in Mityana district, Uganda.

Ensuring Perineal management effectiveness is an important role the midwife must uphold during labour and childbirth. This is because perineal trauma potentially causes significantly, short and long-term maternal morbidity for women. The findings of this study demonstrate that Midwives applied for additional educational training in perineal management, especially, in prevention strategies. There were requests for the most up-to-date research and best practice recommendations to guide midwifery perineal management. This displays midwives' enthusiasm for continuously evaluating their practice and commitment to life-long learning. It is therefore anticipated that scholarship and educational programs should be tailored towards midwives' needs. This should not only be to improve clinical skills as well as perineal protection techniques, but also to build their confidence in decision making. Findings to this study can add to other emerging evidence on perineal trauma and management to contribute immensely to the updating of the current education programs on perineal management.

\section{Recommendations}

1. Midwives should embark on a 'back to basics approach, they should continuously review the Anatomy and physiology, including the perineum and pelvic floor and mechanism of labour. This paucity of knowledge may be a consequence of the previously limited focus on the anatomy of the perineum in earlier pre-registration midwifery curricula and existing perineal management workshops.

2. Midwives Educators should review the training curriculum for the midwives with the inclusion of the current perineal management. Several ref- erences were made to also include strategies to prevent perineal trauma.

\section{Midwives should crave} continued improvements in perineal management education in Mityana district, Uganda

4. Multidisciplinary workshops should be organized involving midwives and obstetricians to ensure a consistent approach to perineal management.

Information Education and Communication materials including Visuals and videos of perineal trauma and repair should be made available for every learning program as well as in practice areas.

5. A combination of e-learning and traditional face-to-face training integrated into all midwifery learning programs to foster theoretical knowledge and clinical practice. 6.

7. Donor agencies should sponsor researchers to extend this study nationally to include multiple maternity sites and alternative birth settings to increase the generability of the findings.

\section{Strengths and limitations}

This study has provided insight into the confidence and educational needs of the midwives about managing the women's perineum during labour. Convenience sampling was adopted in this study in sites that limit generalisability.

A significant strength, however, is the multiple methods used to collect and analyze the data. The qualitative and quantitative data complement each other and increase the validity of the findings. 
Table 5. References

1) Adegoke, A., Utz, B., Msuya, S. E., \& van den Broek, N. (2012). Skilled Birth Attendants: who is who? A descriptive study of definitions and roles from nine Sub Saharan African countries. PloS one, 7(7), e40220.h ttps://doi.org/10.1371/journal.pone.0040220PMid:22808121 PMCid:PMC3393745

2) Bick, D. E., Ismail, K. M., Macdonald, S. (2012). How good are we at implementing evidence to support the management of birth related perineal trauma? A UK wide survey of midwifery practice. BMC Pregnancy Childbirth12, 57.2012: https://doi.org/10.1186/1471-2393-12-57PMid:22731799 PMCid:PMC3472238

3) Hildingsson, I., Rubertsson, C., Karlström, A., \& Haines, H. (2019). A known midwife can make a difference for women with fear of childbirth- birth outcome and women's experiences of intrapartum care. Sexual \& reproductive healthcare : official journal of the Swedish Association of Midwives, 21, 33-38. https://doi.org/ 10.1016/j.srhc.2019.06.004PMid:31395231

4) Kettle, C., \&Tohill, S. (2011). Perineal care.BMJ clinical evidence, 2011, 1401.

5) $\mathrm{MoH}$ (2018). "Maternal and Child Health Action Plan 2017/2018" Health Sector Strategic Plan III: Ministry of Health, Uganda.

6) Munabi-Babigumira, S., Nabudere, H., Asiimwe, D. (2019).Implementing the skilled birth attendance strategy in Uganda: a policy analysis. BMC Health Serv Res19, 655 (2019).https://doi.org/10.1186/s12913-01 9-4503-5PMid:31500636 PMCid:PMC6734264

7) Radovich, E., Benova, L.,Penn-Kekana, L.(2019). 'Whoassisted with the delivery of(NAME)?'Issues in estimatingskilled birth attendant coveragethrough population-basedsurveys and implicationsfor improving globaltracking. BMJ Glob Health2019;4:e001367.https://doi.org/10.1136/bmjgh-2018-001367PMid:3113945 5 PMCid:PMC6509598

8) Sandall, J., Soltani, H., Gates, S., Shennan, A., \&Devane, D. (2016). Midwife led continuity models versus other models of care for childbearing women. The Cochrane database of systematic reviews, 4, CD004667. pub5https://doi.org/10.1002/14651858.CD004667.pub5

9) Steen, M. (2012).Risk recognition and repair of perineal trauma. British Journal of Midwifery. 20. 768-772. https://doi.org/10.12968/bjom.2012.20.11.768

10) Trochez, R., Waterfield, M., \& Freeman, R. M. (2011). Hands on or hands off the perineum: a survey of care of the perineum in labour (HOOPS). International urogynecology journal, 22(10), 1279-1285. https://doi .org/10.1007/s00192-011-1454-8 https://doi.org/10.1007/s00192-011-1454-8PMid:21611790

11) WHO.(2017). The Global Strategic Directions for Strengthening Nursing and Midwifery.Global Forum for Government chief Nursing and Midwifery Officers on 18 May 2016, Geneva, Switzerland 